\title{
Is It Traditional or Contemporary Marketing Strategy? A Textual Cluster Analysis @MercuBuana_Reg
}

Arissetyanto Nugroho

Email: arissoehardjo@yahoo.com

Yuli Harwani

Email: yuliharwani@yahoo.com

Anggi Dewita

Email: anggidewita27@gmail.com

Janfry Sihite

Email: audio.ian@gmail.com

\author{
Doi:10.5901/mjss.2015.v6n5s5p26
}

\begin{abstract}
The objective of this research is to analyze the contemporary marketing mix activities from one of Indonesian private university twitter account by conducting Textual Cluster Analysis. There are 3140 tweets captured from MercuBuana University twitter account @MercuBuana_Reg, all of these tweets further analyzed using Mixed Method Software Analysis to identify the relevant keywords elements of the marketing mix. The Jaccard Coefficient of co-occurrence and the proximity plot result showed that the twitter marketing communication activities consist of 5 dimension of the contemporary marketing strategy, which are the Product, Price, Place, Promotion, and Process. The keywords clustered in the Product dimension have similarities of character and closeness of relationship are "Architecture, Accounting, Design Communication Visual, Faculty of Technic Planning \& Design, Technic, Industry, Marketing Communication, Civil, Faculty, Major", the keywords in the Price dimension are "Cost, Payment", the keywords in the Place dimension are "Admission, Meruya, Bekasi, Cibubur", the keywords in Promotion dimension are "Scholarship, Manado", the keywords in Process dimension are "Registration, Academic Administration Bureau, Graduation Certificate". Finally the textual cluster analysis concluded that @MercuBuana_Reg conducted selected element of contemporary marketing strategy which are the Product, Price, Place, Promotion and the Process, furthermore @MercuBuana_Reg have to improve the element of people and physical evidence to enhance the university contemporary marketing strategy.
\end{abstract}

Keywords: Textual Cluster Analysis, Marketing Mix, Contemporary Marketing Strategy, Twitter, Mixed Method

\section{Introduction}

The marketing mix is a set of controllable, tactical marketing tools to the target markets (Kotler \& Armstrong, 2010). (Alma, 2008) defines the traditional marketing mix as the concept of 4 marketing element which are the Product, Price, Place, and Promotion. Nowadays, how firms and companies conducting a business has changed because of the Internet (Ainin \& Noorismawati, 2003). The application of internet, termed as the Electronic Marketing (E-Marketing) defined as a new philosophy and a modern business practice of goods, services, information and ideas via the Internet and other electronic means (El-Gohary, 2010). Furthermore, the impact of the internet enabled application on business process development and consumer behavior lead to the traditional 4P marketing mix becomes less relevant (Dehkordi, et al., 2012). Moreover, the traditional $4 \mathrm{P}$ marketing mix should be modified for services due to lack of integration between the variables and relationships, actors, and processes (Shah, et al., 2012).

The university also integrating the internet to enhance the university marketing capabilities toward the target market. Social media such as twitter is one of the internet enabled application that enhance the university capabilities to reach the consumer. Furthermore, the application of twitter for marketing activities over the internet creates basic changes in business and customers behavior, the twitter also provides a unique platform for the firms to understand the 
need of the customers and make the customers free from the time and place to interact with the customer. Twitter also an efficient mode of communication and reduce the cost by omitting unnecessary transaction cost (Sheth \& Sharma, 2005). This research conducted to analyze the dynamic of the university marketing mix application by analyzing the tweet from the university twitter account, since this research will use the university twitter data, therefore this research propose an innovative mixed method application (Textual Cluster Analysis) toward the actual twitter account tweet data.

\section{Literature Review}

\subsection{The Application of Social Media To Enhance The Contemporary Marketing}

(Lovelock \& Wirtz, 2011) describes that the traditional marketing mix cannot manage the customer interface. Therefore, it is necessary to develop a marketing mix by adding 3P associated with services, namely: Process, People, and Physical Environment. 7P marketing mix is more relevant in the contemporary marketing activities in the modern era (Brodie, et al.,, 2008). The contemporary marketing mix has the edge in reinforcing the information than traditional marketing mix (Cao, 2013).

Social media is a tool of the contemporary marketing mix (Cao, 2013). The main purpose of using social media in marketing is to strengthen brand awareness and brand exposure. Therefore, social media presence is fundamental for companies. (Cao, 2013). Social media has made it possible for one person to communicate with hundreds or even thousands of other people about products and the companies. The content, timing, and frequency of the social mediabased conversations occurring between consumers are outside managers' direct control. This stands in contrast to the traditional integrated marketing communications paradigm with high control. Therefore, managers must learn to shape consumer discussions in a manner consistent with the organization's mission and performance goals (Mangold \& Faulds, 2009).

Social Media allow firms to engage in timely and direct end-consumer contact at low cost and higher levels of efficiency than can be achieved with more traditional communication tools. It makes Social Media relevant for large multinational firms and for small and medium-sized companies, and even nonprofit and governmental agencies. Using Social Media is not an easy task and may require new ways of thinking, but the potential gains are far from being negligible (Kaplan \& Haenlein, 2010). However, the increasing use of social media in marketing activities have led to competition between organizations (Schüller \& Rašticová, 2011). Organizations are required to be more creative and use new ways of thinking better than the competitors, updating information and take measures the social media users to win the competition (Todi, 2008).

\subsection{The Application of Twitter to Enhance the Marketing Communication}

Twitter is a popular microblogging tool since October, 2006 (Sakaki, et al., 2010). Twitter users tweet about any topic within the 140 character limit and follow others to receive their tweets (Kwak, et al., 2010). Using Twitter for marketing is necessary since 2008 adjacent to the growing user numbers and marketing applications (Bulearca \& Bulearca, 2010).As a microblog with 140 characters, Internet users in Indonesia are using Twitter as a tool to express their existence (Pramudiana \& Dewiningtias, 2012). An estimated 5.6\% tweets sent or about 19 million tweets per day comes from Indonesia. The number of users and great tweet this has great potential to be used (Wibisono \& Faruqi, 2013).

In the past few years, social media has become the most popular communication channels for college student Internet users (Chu, 2011). As it is popular for the student, certain social networking sites establish networks for particular schools and universities activities in order for students to sign up, interact with schoolmates, and participate in online events (Bolotaeva \& Cata, 2011). A higher-education institution should provide prospective students a consistent information and the desired image of its identity. All communication activities should be well prepared and carried out in the necessary order and comprehensive management (Schüller \& Rašticová, 2011).

\section{Methodology}

The method of data analysis in this study is the Textual Cluster Analysis. Textual Cluster analysis conducting a rapid analysis of large amounts of textual data captured from the twitter account, so we could make sense of the consumer response in the twitter account. Furthermore, the Textual Cluster Analysis could reveal the dimension of the conversation conducted for further analysis regard to the dimension explored (Campbell, Pitt, Parent, \& Berthon, 2011).

Researchers conducted a Textual Cluster Analysis with the QDA Miner. QDA Miner (Qualitative Data Analysis) 
consists of 2 software which are WordStat and SimStat, QDA Miner used in this research because it provide exploratory tools to identify keywords and relationships between keywords through co-occurrence method (Silver \& Lewins, 2014). QDA Miner functions as a qualitative data analysis tool that incorporates many quantitative features to enhance the researcher's ability to identify potentially important data patterns. The QDA Miner data coding process includes the familiar QDA tasks of assigning text passages to codes or word tags that reflect particular concepts or qualities of analytical interest, as well as assigning numeric and/or nominal values to categorical, numeric, Boolean, and other variable types (Lewis \& Maas, 2007).

Table 1. Stages of Research Process

\begin{tabular}{|c|l|l|l|}
\hline Stages & Process Activity & Criteria & Remarks \\
\hline 1 & $\begin{array}{l}\text { Downloading tweet from } \\
\text { account twitter } \\
\text { @Mercubuana_Reg }\end{array}$ & $\begin{array}{l}\text { All tweets in the account twitter } \\
\text { @Mercubuana_Reg }\end{array}$ & $\begin{array}{l}\text { There are 3140 data to be analyzed. Preliminary data are presented in } \\
\text { a format to Microsoft excel. The data content is the Tweet ID, } \\
\text { Username, Tweet, Time, Type Tweets, Retweet By, Number of } \\
\text { Retweets, Hashtags, Mentions, Name, Location, Web, Bio, Number of } \\
\text { Tweets, Number of Followers, Following Number, and Location } \\
\text { Coordinates. }\end{array}$ \\
\hline 2 & Tweet screening & $\begin{array}{l}\text { Analyzing all tweets related to the } \\
\text { contemporary marketing mix: Product, } \\
\text { Price, Place and Promotion, Process, } \\
\text { People and Physical Environment. }\end{array}$ & $\begin{array}{l}\text { Text data that is not relevant to the purpose of the study will be } \\
\text { removed from the files. }\end{array}$ \\
\hline 3 & $\begin{array}{l}\text { Tweets obtained after the previous } \\
\text { screening were collected into one } \\
\text { document and conducting analysis with } \\
\text { QDA Miner }\end{array}$ & $\begin{array}{l}\text { Tabulating frequency of all the keywords and phrases } \\
\text { Content Analysis }\end{array}$ & Keyword screening \\
\hline 5 & Phrase screening & $\begin{array}{l}\text { Excluding words that do not need to be } \\
\text { analyzed in discourse analysis }\end{array}$ & $\begin{array}{l}\text { Phrases that have a frequency less than 10 listed into the exclusion list. } \\
\text { list. }\end{array}$ \\
\hline 6 & $\begin{array}{l}\text { Analyzing keywords and need to be } \\
\text { phrases collected after } \\
\text { the screening }\end{array}$ & $\begin{array}{l}\text { Conducting cluster mapping through } \\
\text { combinations of clusters that suits best }\end{array}$ & Selecting the best cluster and proximity plot \\
\hline 7 & Cluster analysis & Analyzing every cluster & Focusing analysis on the construction of "Contemporary Marketing Mix" \\
\hline
\end{tabular}

\section{Data Analysis}

The results of the Textual Cluster Analysis output in this research suggests that there are four dimensions that revealed from the analysis. Based on the results output through Dendogram can be seen that some keywords have a small distance and others had large distances. That is the keyword that has a small distance has a close relationship or a high degree of similarity, the keyword with a great distance had a low degree of similarity. By looking at the value of Jaccard's Coefficient, the keyword is approaching 1.0 is a keyword that has a close relationship closeness (Talamini, Wubben, \& Dewes, 2013). More detail can be seen in the following figure:

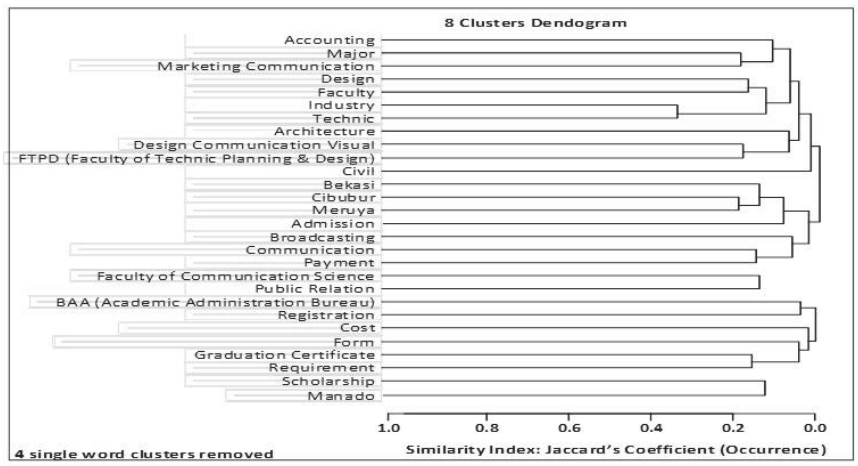

Figure 1. Eight Clusters Dendogram 
However, the output in Figure 1 show the close relationship that has not been exclusively specific. It is, therefore, necessary to conduct modifications for the Number of Cluster to obtain a more specific group. The results output by increasing the Number of Clusters can be seen in the image below:

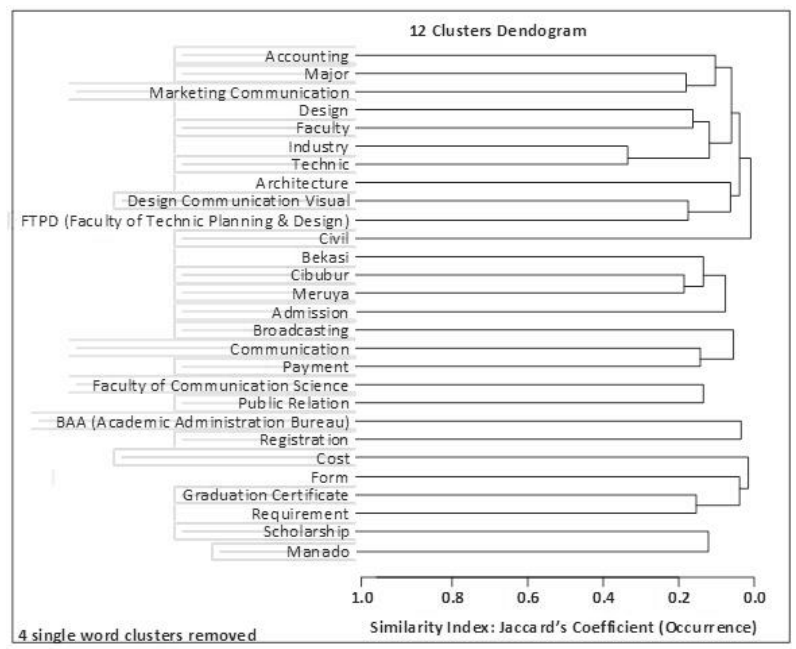

Figure 2. Twelve Clusters Dendogram

The results of Textual Cluster Analysis output can also be seen through the 2D Map, where the output is displayed in the form of words in a circle of each clusters. Through 2D Map, it can be seen that the larger circle indicates the keyword that more dominant while the small circles indicate that the frequency is lower. More detail can be seen in the following figure:

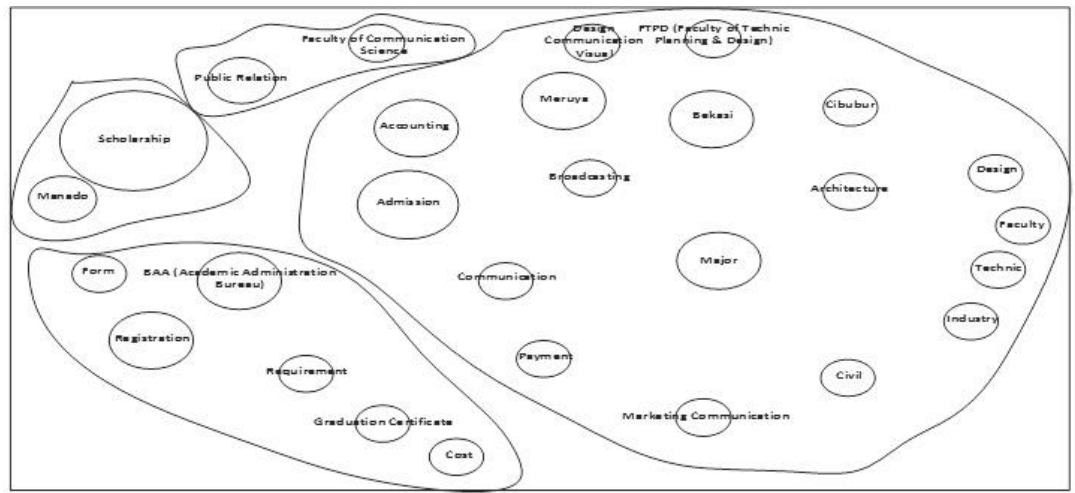

Figure 3. Eight Clusters 2D Map

In figure 3 can be found that there are only four groups and is dominated by one cluster. To get a more powerful grouping the necessary modifications to the number of cluster groups as shown in figure 4.

After improving the Number of Cluster, it discovered that the keyword "Cost" does not appear in the output. This happened because the keyword does not have a group with the same character that is missing from the output. However, the group will be analyzed as having conformity with the marketing mix construct discussed in this study. Here it can be seen that by modifying the Number of Clusters, it formed seven groups according to the clusters that spreads the relationship of each keyword. 


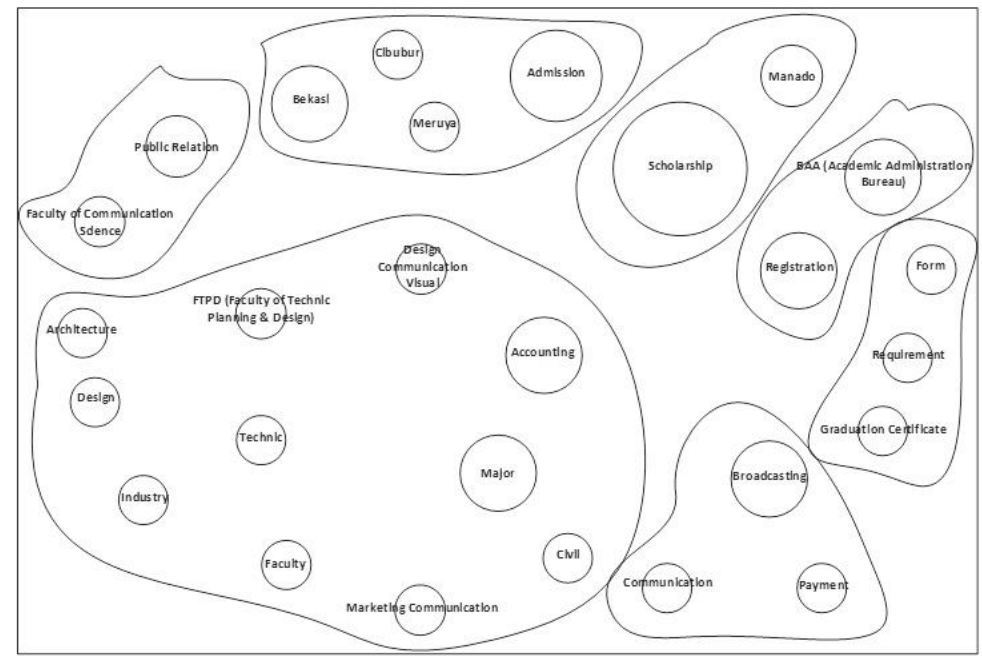

Figure 4. Twelve Clusters 2D Map

In addition through Dendogram and 2D Map, the output of the Textual Cluster Analysis can also be viewed through the 3D Map. The view of the 3D output is not much different from the 2D Map where every keyword will appear in a coloured chart (displayed in circle). The dominant keyword will display as a higher bar chart, the lesser dominant keyword will display as a lower bar chart. Bar chart of the same clusters adjacent to each other and form a group. Similarly, the output results in Dendogram and 2D Map, needs to be modified to produce a more specific clusters and each keyword can form a group to be able to represent the marketing mix construct.

\section{Findings}

\subsection{Description of Product Cluster Analysis}

Based on the output of the Textual Cluster Analysis in Figure 4, the keywords displayed with the largest circle is the most dominant group of keywords. Keywords in the group are "Architecture, Accounting, Design Communication Visual, Design, Faculty of Technic Planning \& Design, Technic, Industry, Marketing Communication, Civil, Faculty, Major". The keywords clustered in a group because it has a similarity of character and closeness of the relationship. This group presented information related to the products offered by the University Mercu Buana, therefore this group is called the Product group.

Table 2. Total Keywords in Product Cluster

\begin{tabular}{clc}
\hline No & Keyword & Tweet \\
\hline 1. & Major & 81 \\
2. & Technic & 41 \\
3. & Faculty & 37 \\
4. & Accounting & 35 \\
5. & Public Relation & 32 \\
6. & Design & 30 \\
7. & Architecture & 22 \\
8. & Industry & 21 \\
9. & Broadcasting & 20 \\
10. & Marketing Communication & 20 \\
11. & Faculty of Communication Science & 17 \\
12. & Design Communication Visual & 15 \\
13. & Communication & 10 \\
\hline
\end{tabular}


In table 2 the keyword "Public Relation, Broadcasting, Faculty of Communication Science, Communication" are also included in the product category. Although in figure 4 "Public Relation, Faculty of Communication Science" form a cluster and "Broadcasting, Communication" another cluster. The reasons which led to the four keywords inserted into a category of product because basically the keyword is part of the product cluster, but because it has very close relationship closeness with other keywords so that the keywords separated form his own group.

Description of Price Cluster Analysis

There is no group for "price" appears in the analysis, however, there are some keywords that spread and merge into another cluster, which are the keywords "Cost, Payment". Although they didn't form in a group, the keyword "Cost" tends to cling to the Process dimension, since there are no costs incurred by prospective students.

The keyword "Payment" means the product and the cost (payment) to consume the product. That is why the keyword "Cost, Payment" incorporated into a particular cluster because it has a close relationship. Given the costs and payments are part of the construct of the price, so in this study the two keywords are considered to have a cluster of its own.

Description of Place Cluster Analysis

The results of the Textual Cluster Analysis output can be seen in Figure 4. The group of keywords which represent a description of the location of the University of Mercu Buana is a place cluster. The keyword group consists of "Admission, Meruya, Bekasi, Cibubur".

These four keywords are in the same group have a similar character that represents the location dimension of Mercu Buana University. Although the keyword "Admission" is not part of the location, but it has a close relationship with the other keywords. This can be seen from the location of tweets asking for registration for prospective students to "Admission" incorporated into the same group representing the construct of places of the marketing mix.

Table 3. Total Keywords in Place Cluster

\begin{tabular}{clc}
\hline No & Keyword & Tweet \\
\hline 1. & Admission & 59 \\
2. & Meruya & 51 \\
3. & Bekasi & 36 \\
4. & Cibubur & 30 \\
\hline
\end{tabular}

In table 3 can be found that the "Meruya" is the location of the most talked about social media through twitter. This happens because Meruya is the main campus of the University of Mercu Buana. While Bekasi and Cibubur frequency is lower because it is a new location Mercu Buana University so that the information known to the public is limited.

Description of Promotion Cluster Analysis

Figure 1 shows that the keywords "Scholarship, Manado" form a group and very close between the two keywords. Both represented the construct of promotion in the marketing mix. The promotion was an attempt by the organization to attract attention, convey information, persuade and remind the products or services offered to the target market. In this case, Mercu Buana University seeks to convey information to the public regarding the scholarship program offering. This offering aimed to attract attention and remind the public of the existence of Mercu Buana University. While the closeness of the relationship between the "Scholarship" with "Manado" caused by surrounding the promotion of the scholarship program organized by Mercu Buana University in Manado gained a lot of responses from the public, so often two keywords that appear in the same tweet.

Description of Process Cluster Analysis

Based on the output of the Textual Cluster Analysis in Figure 4 can be found that the light blue group consisting of the keyword "Registration, Academic Administration Bureau, Requirement, Form, Graduation Certificate" is part of the process. The process of interactive services and attitude of employees must be delivered to the customer in the best way so that the process becomes a major determinant of customer satisfaction. In this case the procedure to become a student at the University of Mercu Buana clearly informed and is expected to facilitate prospective students (the target market). 
Table 4. Total Keywords in Process Cluster

\begin{tabular}{clc}
\hline No & Keyword & Tweet \\
\hline 1. & Registration & 69 \\
2. & Academic Administration Bureau & 63 \\
3. & Requirement & 30 \\
4. & Form & 20 \\
5. & Graduation Certificate & 15 \\
\hline
\end{tabular}

From Table 4 can be found that all the existing processes got a pretty good response from the respondent. It is shown from the frequency of questions and answers submitted relevant with all the activities in Mercu Buana University.

\section{Conclusion and Managerial Implications}

The results of the Textual Cluster Analysis on Mercu Buana University twitter account revealed that there are only 5 dimensions of the marketing mix, which are Product, Price, Place, Promotion, and Process. Although the Mercu Buana University twitter had been delivering a good relation with the prospective target, the dimension of the physical evidence and people didn't appear dominant in the social media marketing strategy conducted. To be able to perform a good contemporary marketing strategy implementation, the Mercu Buana University twitter account should deliver variety of information and developing a good relationship regards to the physical evidence and the people dimension of the Mercu Buana University.

\section{References}

Ainin, S., \& Noorismawati, J. (2003). E-commerce stimuli and practices in Malaysia. PACIS 2003 Proceedings, 38.

Alma, B. (2008). Pengantar Bisnis.

Bolotaeva, V., \& Cata, T. (2011). Marketing Opportunities withSocial Networks. Journal of Internet Social Networking and Virtual Communities, 1-8. doi: 10.5171/2011.409860

Brodie, R. J., Coviello, N. E., \& Winklhofer, H. (2008). Contemporary Marketing Practices research program: a review of the first decade. Journal of Business \& Industrial Marketing, 23(2), 84-94. doi: 10.1108/08858620810850191

Bulearca, M., \& Bulearca, S. (2010). Twitter: a viable marketing tool for SMEs. Global Business and Management Research: An International Journal, 2(4), 296-309.

Campbell, C., Pitt, L. F., Parent, M., \& Berthon, P. (2011). Tracking Back-Talk in Consumer-Generated Advertising: An Analysis of Two Interpretative Approaches. Journal of advertising research, 51(1), 224. doi: 10.2501/jar-51-1-224-238

Cao, Y. (2013). Why do companies need to construct and implement social media marketing strategies?

Chu, S.-C. (2011). Viral advertising in social media: Participation in Facebook groups and responses among college-aged users. Journal of Interactive Advertising, 12(1), 30-43.

Dehkordi, G. J., Rezvani, S., Rahman, M. S., Nahid, F. F. N., \& Jouya, S. F. (2012). A Conceptual Study on E-marketing and Its Operation on Firm's Promotion and Understanding Customer's Response. International Journal of Business and Management, 7(19), 114-124.

El-Gohary, H. (2010). E-Marketing-A literature Review from a Small Businesses perspective.

Kaplan, A. M., \& Haenlein, M. (2010). Users of the world, unite! The challenges and opportunities of Social Media. Business Horizons, 53(1), 59-68. doi: 10.1016/j.bushor.2009.09.003

Kotler, P., \& Armstrong, G. (2010). Principles of marketing: Pearson Education.

Kwak, H., Lee, C., Park, H., \& Moon, S. (2010). What is Twitter, a social network or a news media? Paper presented at the Proceedings of the 19th international conference on World wide web.

Lewis, R. B., \& Maas, S. M. (2007). QDA Miner 2.0: Mixed-Model Qualitative Data Analysis Software. Field methods, 19(1), 87-108. doi: $10.1177 / 1525822 \times 06296589$

Lovelock, C. H., \& Wirtz, J. (2011). Services marketing: people, technology, strategy: Pearson.

Mangold, W. G., \& Faulds, D. J. (2009). Social media: The new hybrid element of the promotion mix. Business Horizons, 52(4), 357-365. doi: 10.1016/j.bushor.2009.03.002

Pramudiana, Y., \& Dewiningtias, A. (2012). The Utilization of Twitter Social Media and Its Benefit toward the Development of Audience Community in Indonesia's TV Industry. International Proceedings of Economics Development \& Research, 28.

Sakaki, T., Okazaki, M., \& Matsuo, Y. (2010). Earthquake shakes Twitter users: real-time event detection by social sensors. Paper presented at the Proceedings of the 19th international conference on World wide web.

Schüller, D., \& Rašticová, M. (2011). Marketing Communications Mix of Universities, Communication with Students in an Increasing Competitive University Environment. Journal of competitiveness.

Shah, D., Kumar, V., Qu, Y., \& Chen, S. (2012). Unprofitable cross-buying: evidence from consumer and business markets. Journal of 
Marketing, 76(3), 78-95.

Sheth, J. N., \& Sharma, A. (2005). International e-marketing: opportunities and issues. International Marketing Review, 22(6), 611-622. Silver, C., \& Lewins, A. (2014). Using software in qualitative research: a step-by-step guide.

Talamini, E., Wubben, E. F., \& Dewes, H. (2013). The Macro-Environment for Liquid Biofuels in German Science, Mass Media and Government. Review of European Studies, 5(2), p33.

Todi, M. (2008). Advertising on social networking websites. Wharton Research Scholars Journal, 52.

Wibisono, Y., \& Faruqi, N. (2013). Penentuan Gender Otomatis Berdasarkan Isi Microblog Memanfaatkan Fitur Sosiolinguistik. Jurnal Cybermatika, 1(1). 